\title{
Performing the Unspeakable. Intermedial Events in András Jeles's Parallel Lives
}

\author{
Judit Pieldner \\ Sapientia Hungarian University of Transylvania (Miercurea Ciuc, Romania) \\ E-mail: juditpieldner@gmail.com
}

\begin{abstract}
Among the various connotations of intermediality one is related to the performative aspect of the term. As Ágnes Pethő $(2011,42)$ formulates: "Intermediality is seen, more often than not, as something that actively 'does,' 'performs' something, and not merely 'is." This notion of intermediality implies a dynamic category within which media constellations are in continuous motion, being reconfigured by one another, the cinematic medium becoming a playground of media interactions. András Jeles, Hungarian experimental filmmaker formulates the paradox that a particular medium can best express its own mediality through the "foreign" material of other arts and media. The medial consonances and dissonances transform the cinematic medium into a liminal space where meaning as event can take shape. Jeles's film entitled Parallel Lives (Senkiföldje, 1993) is aimed at such event-like liminality in several respects: culturally, it turns towards a burdened site of the still unprocessed past of the Hungarian society; thematically, it addresses the topic of the Holocaust; and medially, it proposes to artistically render the unrepresentable. The film appeals to the other arts, incorporating a set of literary, painterly and musical allusions that contrast a culturally aestheticized view of the child in pain with the ultimate, inescapable and incommensurable reality. ${ }^{1}$
\end{abstract}

Keywords: the real vs. the intermedial, intermediality as event, tropes of the unrepresentable, archival footage, András Jeles.

\section{Figuring the Infigurable}

The present article addresses possible ways in which the real is configured in the interplay of different media within the cinematic medium. It investigates how various media constellations can be caught, in Brigitte Peucker's terms, in the act of "gesturing toward the real," of "figuring the real," which is by nature inherently

1 This work was supported by a grant of the Romanian Ministry of National Education, CNCS UEFISCDI, project number PN-II-ID-PCE-2012-4-0573. 
unrepresentable. My research deals with ways in which the crisis of representation is addressed by particular moments of intermedial figurations that fold back onto the real and assist "the movement between the representation and the real" (Peucker 2007, 9). In the introduction to her book entitled The Material Image. Art and the Real in Film, Brigitte Peucker states: "It is only seemingly a paradox that the real and its relation to representation are centrally at issue in the trompe l'oeil and tableau vivant moments that occur in film - in the visual games, that is, that film plays with reality. Aesthetic practices such as these serve as occasions for staging the real in its relation to representation" (Peucker 2007, 1-2).

In mapping the rhetoric of intermedial cinema in her book Cinema and Intermediality. A Passion for the In-Between, among the various connotations implied by the term intermediality, Ágnes Pethő draws attention to the performative aspect inherent in it: "Intermediality is seen, more often than not, as something that actively 'does,' 'performs' something, and not merely 'is'” $(2011,42)$. Thus, the notion of intermediality implies a dynamic category within which media constellations are in continuous motion, being reconfigured by one another, the cinematic medium becoming a playground of media interactions and meaning emerging out of the tensions, collisions, on the boundaries, in-between.

In relating intermediality to the domain of the figural, Joachim Paech's statement can serve as a premise: "the trace of the medium would become describable as a figured process or a configuration in the film" (Paech 2000). In researching the figurations of intermediality, the "figured permeability" (Peucker) between the real and the image, I am particularly interested in the figural brought in relation to the real experienced as trauma, and related to this, in the relation between the discourses of trauma and the discourses of intermediality. As trauma is a liminal experience of the real that particularly resists representation, and any attempt at authentic representation is strewn with pitfalls, I examine the role of media confluences and differences in rendering the unspeakable, or in Lyotard's terms, in figuring the infigurable. In examining the role of visual media in literary representations of traumatic experiences, Christof Decker develops the argument that "Mixed media often signal a lack of the visible and the knowable, yet by creating hybrid forms of signification, they can also be understood as highly reflexive and creative responses to this feeling of lack. The act of 'mixing,' therefore, as a semiotic as well as technological process, may have two major implications: firstly, it evokes something that is not visible and cannot be represented; secondly, it creates multi-layered, hybrid objects that are aesthetically complex and rich in connotations" (Decker 2012). In a similar way, intermedial figurations may act as 
tropes of the unrepresentable within the texture of film, allowing for the presentness of the threshold experience and providing the sensory-affective engagement of the spectator.

\section{András Jeles's "Critical Cinema”}

The main reason why András Jeles has remained mostly unknown in an international context may be that his films are thematically closely related to the Hungarian socio-cultural context. He is situated at the periphery also within Hungarian cinema, because he creates extremely bizarre and disquieting parables of human existence in the not easily digestible language of cinematic experimentation. He started his career within the confines of state socialism, when experimental filmmaking was a form of cultural resistance embedded in the alternative/underground cultural movements and also a form of representational resistance, strongly defying the conventions of mainstream cinema. Hungarian experimental filmmaking does not refer to a particular mode of cinematic expression, but it embraces a plethora of artistic endeavours that have manifested mostly within the confines of the Béla Balázs Studio. As many artists coming from the field of the other arts, especially fine arts, also pursued their activity within the thriving workshop of the BBS, a strongly intermedial spirit evolved in the Studio, in line with the medial expansion of the 1970s and 1980s. Most of the artists creating in the studio were transgressing the media boundaries and exploring the conflations and tensions of media differences, such as among painting, photography and film (Dóra Maurer); film, literature and happening (Miklós Erdély, Tamás Szentjóby); painting, music, theatre and film (László feLugossy); film and video (Gábor Bódy); fine arts and theatre (Ilona Keserü, Gyula Pauer); film and theatre (András Jeles). Theatre is a determining part of Jeles's artistic career; he creates a unique theatrical discourse that deviates from the institutional system of theatre, representing alterity even in the context of alternative theatre. Two of Jeles's theatrical performances were recorded onto film within the Béla Balázs Studio: Dramatic Events (Drámai események, 1985) and The Empire of Smiles (A mosoly birodalma, 1987).

András Jeles, disciple, together with Gábor Bódy, of the great "father-figure" of Hungarian neo-avant-garde, Miklós Erdély, wished to relieve Hungarian cinema of the ideological sediments that restricted the possibilities of expression. The cinematic discourse elaborated by him radically deviates from the classical mode of narration in the Bordwellian sense, as well as from the representational templates 
of both documentary and fiction. Jeles considers stylization as a way out of both documentary realism and feature film narrative. At Jeles stylization implies, in the first place, consistently playing off the forms of fiction and documentary against each other, reaching into further deconstructive gestures. His first feature film, entitled Little Valentino (A kis Valentinó, 1979) was already made in this spirit, in which the documentary-like tonality is mingled with stylized role-plays; the text written over the image signals the influence of Godard and the French New Wave cinema. The adolescent protagonist is in search of his identity against the backdrop of 1970s Hungary; the film examines the relationship between the individual and society by aligning to neither alternative of representational modes. [Fig. 1.] Jeles's next film, the highly subversive Dream Brigade (Álombrigád, 1983), which was banned, and presented to the public only after 1989, shifts the perspective from the individual to a social group, that of the working class. [Fig. 2.] It is a parody of the propaganda film of the 1950s, in which the destructive apparatus of the film penetrates into all levels, from the mise-en-scène through composition and structure, to the relationship of sound and image.

In the next year, Jeles made The Annunciation (Angyali üdvözlet, 1984), a screen adaptation of a Romanticist philosophical poem of Hungarian literature, Imre Madách's The Tragedy of Man, which constitutes yet another shift of perspective, this time to the scale of universal human existence. In both, the Dream Brigade and The Annunciation, Jeles employs non-professional actors. The four adapted scenes of the Tragedy are acted by children, in this way The Annunciation contrasts the tragic depths of existence with children's innocent naivety, resulting in a grotesque and revelatory quality of the moving image. [Figs. 3-4.] For Jeles, the child actor is a kind of mask, carrying energies other than adult actors, endowed with the capacity of expressing through concealing, in a state of oblivion. Acting requires a mode of expression that is beyond the capacity of professional adult actors, whether male or female; a Third is needed, namely the child actor, who, through "its" genderless and unprofessional acting, is capable of rendering the foreignness of existence (cf. Jeles 2006, 30).

The child's perspective and the unprocessable trauma of the Holocaust are contrasted in Jeles's next film, Parallel Lives, a. k. a. Why Wasn't He There? (Senkiföldje, 1993), in which Jeles eschews the iconic images of the Holocaust in favour of narrating the events prior to deportation through the diary of an adolescent girl, along with the intermedial representation conjoining literature, painting and music, as well as archival footage of the child in pain, the child facing death. Ten years passed until his next film, Joseph and his Brothers - Scenes from 
a Peasant Bible (József és testvérei - Jelenetek egy parasztbibliából, 2003), which counterpoints two stories of human exposedness told in different registers: the biblical story of Joseph and his brothers narrated in form of a shadow play, as well as a prostitute's story recorded with an infrared camera, both techniques leading out of the realm of cinematic familiarity. [Figs. 5-6.]

Jeles's cinematic art deviates from generic standards and commercial uses. Whether in the recurrent theme of (individual, ethnic, social or universal) alienation or through the techniques aimed at creating non-filmlike films, Jeles is particularly motivated by the urge to depict foreignness in a revelatory way, by creating disconcerting interfaces through which film medium faces its Other. He is attracted by themes and forms that resist representation, dips the cinematic discourse into crisis and gropes its limits only to return from beyond the boundaries of cinema, allowing meaning to take shape as event, mostly achieved through the presence of the "otherness" of the other arts.

According to him, a particular medium can best express its own medial character and display its own materiality by getting close to the foreign matter of some other medium: "There seems to exist a peculiar tendency in art: to create forms which bring to the surface the most profound and mysterious features of the matter [...]. It is a shocking paradox: if the form makes visible its own material, if the medium reveals its most specific qualities, then it almost leaves the sphere of its own possibilities and approaches a foreign territory, the language of another medium" (Jeles 2006, 8, translation mine).

Painting gains special significance in Jeles's films. In his view, the answer to the question what film can learn from painting lies by no means in the painterly quality or painterly composition. What links the two media, according to Jeles, is handling the material in such a way that it reveals what lies beyond the matter. Jeles regards the moving image as a means to evoke the invisible: "It is not the lighting or the handling of central perspective (etc.) that film should take over from painting - as sharply different conditions prevail in the two media in this respect - but rather the painterly mentality, the incessant vigilance, the dread and despair arising in front of the white surface, the tension between total naivety and total professional readiness, the childish guidance of the work of the hand, as well as the humble acceptance of the task that the visible image serves to evoke the invisible - in other words, that painting is a sacred activity" (Jeles 2006, 24, translation mine). The painterly allusion in the title of The Annunciation serves as the indication of this sacred dimension, as an urge to seek in film the invisible looming through the surface of the visible, evoking "the aesthetic regime of the 
image" (Rancière, 2006) and the metaphysical view of Romanticism - with the express aim of deconstructing the metaphysical horizon of human thinking.

\section{Literature, Painting, Music and Archival Footage: Tropes of the Unrepresentable in András Jeles's Parallel Lives}

András Jeles's Parallel Lives, a. k. a. Why Wasn’t He There? (Senkiföldje, 1993) is a full-length feature film, also containing archival footage. It addresses the individual and collective trauma of the Holocaust, which resists representation and transforms the attempt of mediation, whether at the level of private memory or that of artistic representation, into the crisis, the trauma of representation. In her study Jewish Identities and Generational Perspectives, Catherine Portuges (2012) surveys the site of Hungarian films made after 1989 addressing the Holocaust, and discusses the variety of representational modes in fictional, documentary and experimental formats (historical frescoes, transgenerational or intimate personal narratives, flashback, real-time documentary investigation, physically (re-)entering the places of memory, etc.). Jeles eschews the pitfalls of grand narratives or direct mise en scène by creating a "beautiful, balanced and simple" narrative (Balassa 1993) focusing on episodes of the life of a Hungarian Jewish family prior to deportation, as documented in the fictional diary of a thirteen-year-old girl. [Figs. 7-8.]

Whereas Claude Lanzmann's Shoah (1985) focuses on the Endlösung, Jeles turns the attention towards the antecedents. The film represents the process of disintegration of family and personality, of family members becoming foreigners in their home. It follows how hysteria and compulsive neurosis creep up on the family, in genre episodes presented through the focalization of the fallible perspective of the child, through the perception of the diary which documents two years' events, from 1942 to 1944. The film faces the crisis of representation by an awareness of unrepresentability: the voice-over is that of the adolescent girl, Éva Münzer, who is also the protagonist of the story, a possible Hungarian Anne Frank, but who conveys a deep sense of disintegration as what is going on around her is beyond comprehension. From this perspective, it is the personal episodes and objects, the birthday party, the deportation of the family of Éva's cousin, the red bicycle and its absent owner, the fate of Uncle Münzer's last coat, that get to the fore. [Figs. 9-10.] The last episode of the film shows Éva being raped by a gendarme; then the diary stops, the story does not continue. 
Needless to mention the profound interconnectedness of child and cinema or the role of children as the most vulnerable protagonists in various representations of the Holocaust: Somewhere in Europe (Valahol Európában, Géza von Radványi, 1947), Fateless (Sorstalanság, Lajos Koltai, 2005), Schindler's List (Steven Spielberg, 1993) attest to the immediacy, intimacy and "aural richness" (Lebeau $2008,16)$ that the figure of the child confers on the moving image. The child is the figure that stands for "the claims of the moving pictures to document the spontaneity and immediacy of 'life' itself" (Lebeau 2008, 13). In Jeles's cinema, the child before the camera is situated in-between the anthropological and the artistic sense of playing, simultaneously inside and outside, standing for the artistic truth that "emerges into the unconcealedness of its being" in the Heideggerian sense (Heidegger 2001, 35).

"I don't understand," the restrained voice-over of the child repeats again and again. In contrast, the camera does: the intruding, lurking, ubiquitous camera performs the gaze of the power. Voice and image act as dissonant agents, playing off one against the other. While Éva's diary documents the endangered intimacy of existence, the voyeur camera, lurking from beyond doors and curtains, infecting private sphere and interpersonal relations, records the gradual degradation and implosion of the family, reinforcing the feeling that there is nowhere to escape. The tension between the limited knowledge conveyed by the voice-over and the omniscience of the camera dramatizes the unresolvable dissonance between childhood intimacy and the irreversibility of destruction.

In rendering ultimate reality which is, on its own, inherently unrepresentable, infigurable, the film calls upon the other arts, systematically incorporating a set of literary, painterly and musical allusions that act as intermedial figurations in the texture of the film, making it dense and porous at the same time, being involved in the dynamics of simultaneously concealing and revealing the dimensions of the real. The film carries out the "gesturing toward the real" by inviting the representational modes of other arts. It has to be mentioned from the outset that the literary, painterly and musical references to Goethe, Dickens, Caspar David Friedrich, and Mozart, Schubert and Wagner respectively, all belong to the classical tradition of the Enlightenment and Romanticism, several of which revolve around the exposedness, suffering and death of children. Thus, one of the interpreters of the film, Gábor Schein (2004) is right when he claims that there is an implied intertextual reference to the lines in Rilke's Duino Elegies that point at the profoundly unsettling issue of who is responsible for the death of children: "Who will depict a child just as it stands? - place it / within its constellation, give it the measure of distance / into 
its hand? Who make the death of children / out of grey bread, which hardens like a stone, / or place it in the cherry mouth as it were the core / of a shiny apple? Murderers are / easy to fathom. Only this: to take on death / completely, before even life begins, / contain it lightly and without complaining, / bereaves description." The evoked artistic references seem to emerge from the aesthetic experience of the child protagonist herself, who insulates bare reality and, as a defence mechanism, compensates for the loss experienced in life with the gain of imagination. Beyond this, the employment of classical cultural heritage reveals an awareness of the cultural determinedness of experience, of the fact that the communicability of experience is culturally coded, depending upon and carried by prior cultural images. In this way, Jeles's film contrasts a culturally aestheticized view of the child in pain, the child in death with the ultimate, inescapable and incommensurable reality. Folding upon one another, the immediacy of the real and the hypermediated experience of artistic rendition also address the working of cultural memory, the consubstantiality of (inter)mediality and the mediatedness of memories, as well as the inertia of art in the face of the unpardonable sins of humanity.

In parallel with writing her diary, Éva is reading David Copperfield. The protagonist of Dickens's novel steps out of the book, gets animated by the girl's imagination and enters Éva's life as an alter ego or an imaginary friend with whom Éva shares her destiny. Dickens's book starts with the following sentence, which Éva quotes in her diary: "Whether I shall turn out to be the hero of my own life, or whether that station will be held by anybody else, these pages must show." The literary Bildungsroman brings proof of David Copperfield's becoming, indeed, the hero of his own life; this chance, however, is not given to Éva, whose fate recontextualizes literature and at the same time reconsiders its relation with reality. The literary figure of David Copperfield enters the diegesis of the film and becomes embodied as a cinematic figure, standing for a similar destiny of exposedness to the atrocities of the adult world. The parallel (also indicated by the title of the film, Parallel Lives) is made evident in the scene of killing a pig, when the two children are watching helplessly how the adults take pleasure in the brutal - otherwise routine - activity. The memorable literary scene of David Copperfield's being beaten by Mr Murdstone is also embedded in the film, together with a number of other scenes in which Éva is also present, thus she becomes a witness of David Copperfield's fate. Conversely, the literary figure also turns into a witness of Éva's fate. [Figs. 11-12.]

The incorporated literary scenes, simultaneously implying medial difference and contextual analogy, illuminate a non-place, a heterotopia in the diegesis of 
the film, and serve as an intermedial mise en abyme "in which we see not just an 'inscription' of one medium into another, but a more complex 'trans-figuration' taking place, in the process of which one medium is transposed as a 'figure' into the other, also acting as a figure of 'in-betweenness' that reflects on both the media involved in this process" (Pethő 2011, 4). The juxtaposition of fiction and reality in the figures of David Copperfield and Éva Münzer reverberates with the profoundly unsettling affirmation that Jean-Paul Sartre formulated after World War II: "The most beautiful book in the world will not save a child from pain” (Sartre 1970, 233). Vicky Lebeau, in her volume Childhood and Cinema, comments on this passage as follows: "What does it mean to measure the value of literature against the life and death of a child? Part of the significance of Sartre's intervention is that, while it casts the child's body - in pain, in death - as a type of limit to an aesthetic committed to acts of social transformation, it is also speaking out of a long tradition in thinking about the power of representation as, precisely, transformative of pain (a tradition usually derived from Aristotle's well-known commentary on our delight in the realistic depiction of objects that it would be painful to see)" (Lebeau 2008, 136).

In the light of the close connection between Jeles's filmmaking practice and the art of painting briefly outlined above, Parallel Lives also evokes the presence of painting in rendering the unspeakable. The close-ups of house interiors suggesting confinedness are contrasted with the total of the openness of the sea in a manner that evokes Caspar David Friedrich's painterly universe and metaphysical-existential horizon. I am now referring to one single tableau vivant, namely a symbolic setting paraphrasing Caspar David Friedrich's Two Men by the Sea at Moonrise (1817), in which Éva, the narrator-protagonist, and Dickens's hero can be seen together at the seaside. [Figs. 13-14.] Brigitte Peucker regards tableau vivant moments in film as moments of "intensified intermediality" (2007, 26). According to Ágnes Pethő, "the tableau form confers the filmic discourse a degree of constructedness and aestheticism that often emerges in a tense interplay with unsettling subject matters" $(2014,54)$; the tableau vivant performs the "reconnection to a universal cultural heritage of 'grand images"” $(2014,67)$. The spectacle turning into vision, the mystical encounter of sky and water, the perspective running into the infinite, the figures standing with their back being immersed in the spectacle of nature, the finite face to face with the infinite - all these idiosyncratic elements of Friedrich's painting are evoked in the cinematic tableau, which, however, deconstructs the painterly universe by erasing the mystical light and leaving only the huge sea and the cloudy horizon, while the 
children are throwing pebbles into the water and Éva's voice-over says: "I am afraid of the sea. It is so cruel. I saw how it dealt roughly with some of those from among us." The substitution of the painterly figures with children further enlarges the incommensurability and deepens the exposedness of human existence in the face of universal foreignness. Jeles proves to be profoundly disillusioned with the metaphysical construction of Western culture and civilization.

Jeles's film eschews the pitfalls of the visual iconography of the Holocaust and creates a more penetrating intermedial playground, folding the layers of literature, music and painting upon one another within the cinematic medium, allowing for the mediation of liminal experience through the intermedial figurations discussed above. Besides, the film also contains archival footage interweaving the narrative thread with documentary images. The archival footage, albeit representing a return to the real, functions rather as figuration within the texture of the film narrative. In this sense, the archival footage can be viewed not as a set of images evoking the real, constituting some kind of transparent representation within the body of film, but rather as an alternative modality of mediation, creating productive tension and interaction between two distinct sets of moving images. Indexical archival footage embedded into feature film, as an ontological rupture, creates a dynamic structure and inscribes a sense of difference into spectatorial experience. Its presence as figuration may serve as meditation upon time and history, activating in the spectator the documentary consciousness in the sense Vivian Sobchack understands the term, that is, "a particular mode of embodied and ethical spectatorship that informs and transforms the space of the irreal into the space of the real" (Sobchack 2004, 261). Jeles lifts into the narrative particular segments of the Nazi propaganda film on the emptying of the Warsaw ghetto in 1943, in which many children can be seen among those embarked onto trucks to be deported.

Jeles manipulates the archival material, letting the images flow under the scrutiny of a magnifying lens (connecting back to Éva's examining a painting with a magnifying lens and to the images of killing a pig also presented through its filter) [Figs. 15-16], turning the faceless mass into individual faces, thus turning history into a dossier that needs to be reconsidered and the effacing mechanism of historical memory into personal involvement. The most emblematic moment of this documentary material is the dancing of a small crippled boy in front of the soldiers. The haunting indexical presence of children reconnects to the narrative thread of the film and also establishes an intertextual connection with those films that also draw upon the very same Nazi propaganda film. Such are Alain Resnais's Night and Fog (1956), which presents for the first time the image of the small 
boy raising his hands at gunpoint, as well as Ingmar Bergman's Persona (1966), which takes over this photographic image and inserts it into its highly unsettling intermedial texture. [Figs. 17-18.] As Vicky Lebeau (2008, 139) comments: "Captured again by Persona, the photograph becomes a means to represent the precedence, or imposition of memory over lived time: the (still) life that rushes back in to interrupt our moments of being, registering the irruption of personal as well as historical memory."

As a memento, the archival footage condenses the future of the narrated time, which is the past evoked on the film reel. This uncanny "future-in-the-past" turned into presence, the slow, iterative motion of people on the documentary recordings evoked in the closure of the film bitterly counterpointed by the grandeur of the accompanying music, Pamina and Papageno's duet from the first act of Mozart's Zauberflöte, whose story portrays the education of mankind, progressing from chaos through religion and reason, ultimately to make "the Earth a heavenly kingdom, and mortals like gods," provide a cathartic closure that reveals a total disillusionment with the metaphysical and enlightened values and "anthropology of hope" (Balassa 1993) of Western civilization. The closure of Parallel Lives universalizes deportation into a parable of human existence. Beyond condensing the narrative and reinforcing the affective quality of cinematic experience, the intermedial occurrences act in the Heideggerian sense of Ereignis, Er-eignis, that is, in the sense of appropriation, of making one's own, providing medial irruptions that interrupt one's moments of being, and also revelative moments that make one feel the grip of human existence, creating the premises of an embodied spectatorship.

\section{Conclusions}

Jeles's Parallel Lives is a cinematic attempt at medially performing the unspeakable. The film figures the infigurable, on the one hand, through the employment of the child's perspective, turning the figure of the child into an emblem of the exposedness of human existence, and through the employment of a set of classical artistic references, on the other hand. Jeles touches upon the sphere of the unrepresentable through a deconstruction of the metaphysical and rational construction of human civilization evoked in the classical cultural references, which perform the working of cultural memory, but perhaps more significantly, point at the impotence of art and aesthetics in the face of inhumanity. Ultimately, Jeles's film stages the incomprehensibility of the dual nature of 
Western civilization built on the heritage of Enlightenment and Romanticism, the incommensurability of the cohabitation - of the "parallel lives" - of the two faces of human culture, the scale of inhumanity and the aesthetic regime of culture.

\section{References}

Balassa, Péter. 1993. Szépen, nyugodtan, egyszerúen. [In a Beautiful, Balanced and Simple Manner], Filmvilág vol. 36 no. 11: 45-47.

http://www.filmvilag.hu/xista_frame.php?cikk_id=1295. Last accessed 10. 04. 2015.

Decker, Christof. 2012. Trauma Narratives. Mixed Media, and the Meditation on the Invisible. Imaginations vol. 3 no. 1: 92-104.

http://www3.csj.ualberta.ca/imaginations/?p=2939. Last accessed 10. 04. 2015.

Jeles, András. 2006. Teremtés, lidércnyomás. Írások filmról, színházról. [Creation, Nightmare. Writings on Film and Theatre], Budapest: Kijárat.

Heidegger, Martin. 2001. Poetry, Language, Thought. New York: HarperCollins Publisher.

Lebeau, Vicky. 2008. Childhood and Cinema. London: Reaktion Books.

Paech, Joachim. 2000. Artwork - Text-Medium. Steps en Route to Intermediality. http://www.uni-konstanz.de/FuF/Philo/LitWiss/MedienWiss/Texte/interm. html. Last accessed 15. 10. 2014.

Pethő, Ágnes. 2011. Cinema and Intermediality. The Passion for the In-Between. Newcastle upon Tyne: Cambridge Scholars Publishing.

Pethő, Ágnes. 2014. The Tableau Vivant as a "Figure of Return" in Contemporary East European Cinema. Acta Universitatis Sapientiae. Film and Media Studies vol. 9: 51-76.

Peucker, Brigitte. 2007. The Material Image: Art and the Real in Film. Stanford, California: Stanford University Press.

Portuges, Catherine. 2012. Jewish Identities and Generational Perspectives. In $A$ Companion to Eastern European Cinemas, ed. Anikó Imre, 101-124. Malden, MA; Oxford and Chichester: Wiley-Blackwell.

Rancière, Jacques. 2006. The Politics of Aesthetics: The Distribution of the Sensible. New York: Continuum.

Rutherford, Anne. 2013. Film, Trauma and the Enunciative Present. In Traumatic Affect, eds. Meera Atkinson and Michael Richardson, 80-102. Newcastle upon Tyne: Cambridge Scholars Publishing. 
Sartre, Jean-Paul. 1970 [1948]. What is Literature? London: Methuen.

Schein, Gábor. 2004. Holokauszt, képírás. Jeles András: Senkiföldje. [Holocaust, Picture-Writing. András Jeles: Parallel Lives], Metropolis vol. 8 no. 4: 54-63.

Sobchack, Vivian. 2004. The Charge of the Real: Embodied Knowledge and Cinematic Consciousness. In Carnal Thoughts: Embodiment and Moving Image Culture, 258-285. Berkeley, Los Angeles and London: University of California Press.

\section{List of Figures}

Figures 1-2. The individual vs. the social apparatus. András Jeles: Little Valentino (A kis Valentinó, 1979) and Dream Brigade (Álombrigád, 1983).
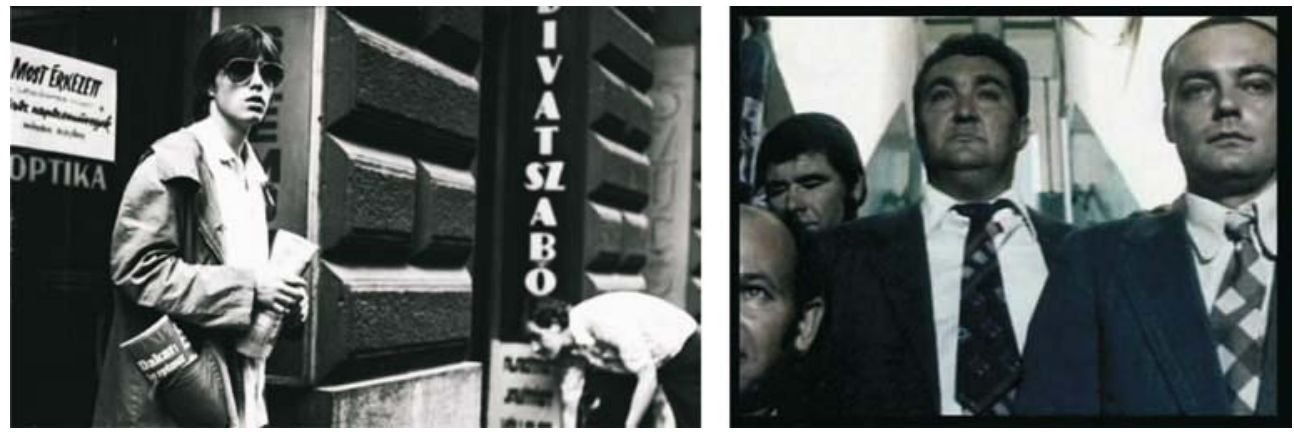

Figures 3-4. The "aural richness" of the child in András Jeles's The Annunciation (Angyali üdvözlet, 1984).
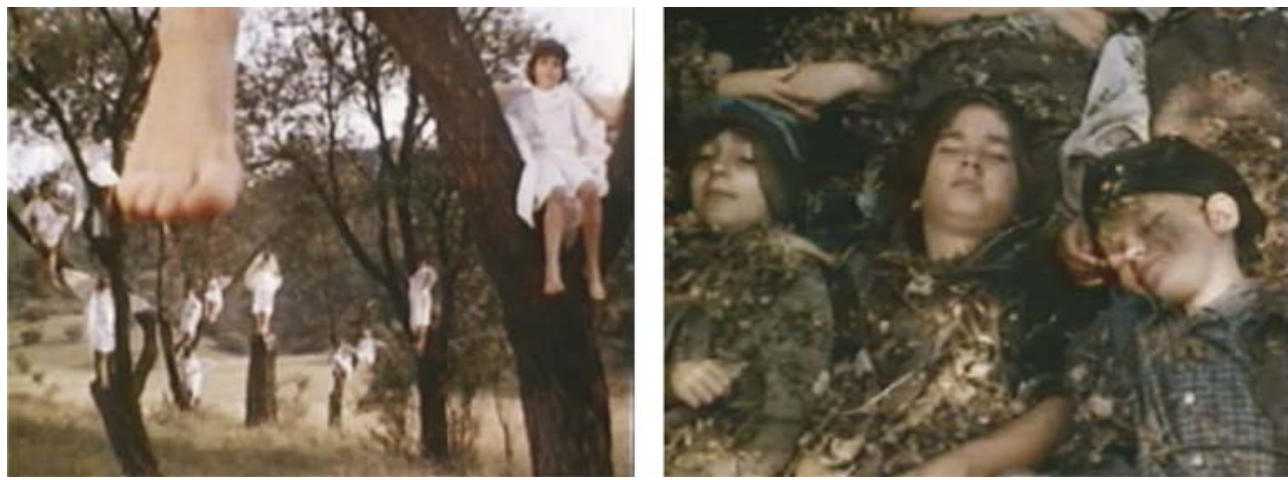
Figures 5-6. Juxtaposition of shadow-play and infrared camera recordings in András Jeles's Joseph and His Brothers - Scenes from a Peasant Bible (József és testvérei - Jelenetek egy parasztbibliából, 2003).
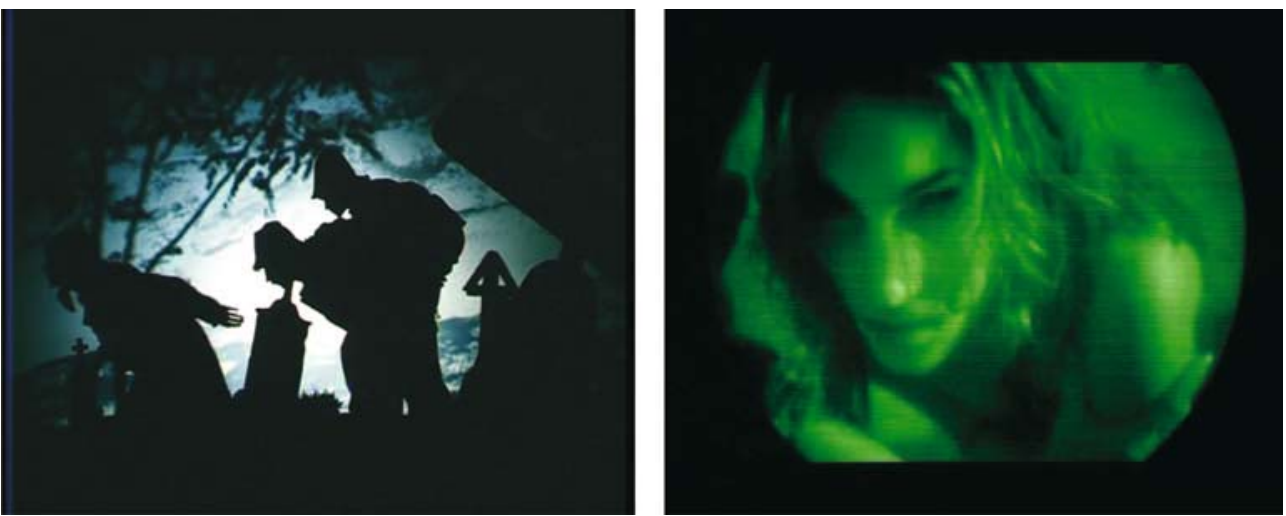

Figures 7-8. The protagonist-narrator of András Jeles's Parallel Lives (Senkiföldje, 1993).
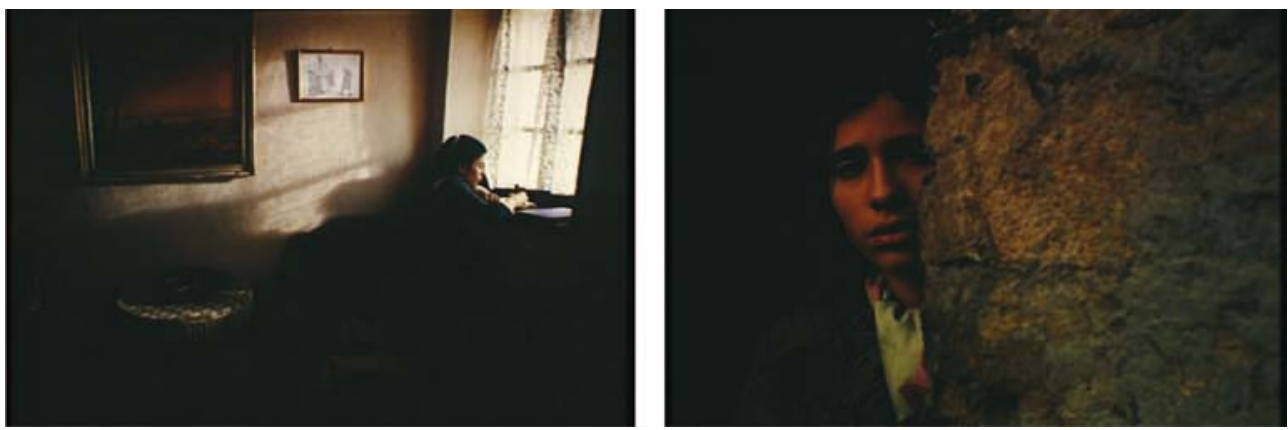

Figures 9-10. The memory of objects. András Jeles: Parallel Lives
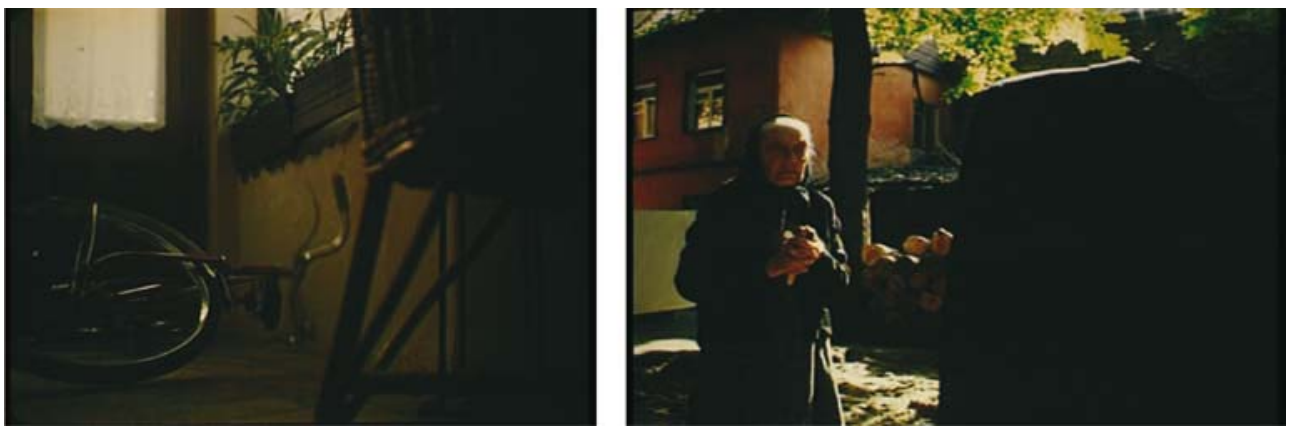
Figures 11-12. The juxtaposition of the figures of David Copperfield and Éva Münzer in András Jeles’s Parallel Lives.
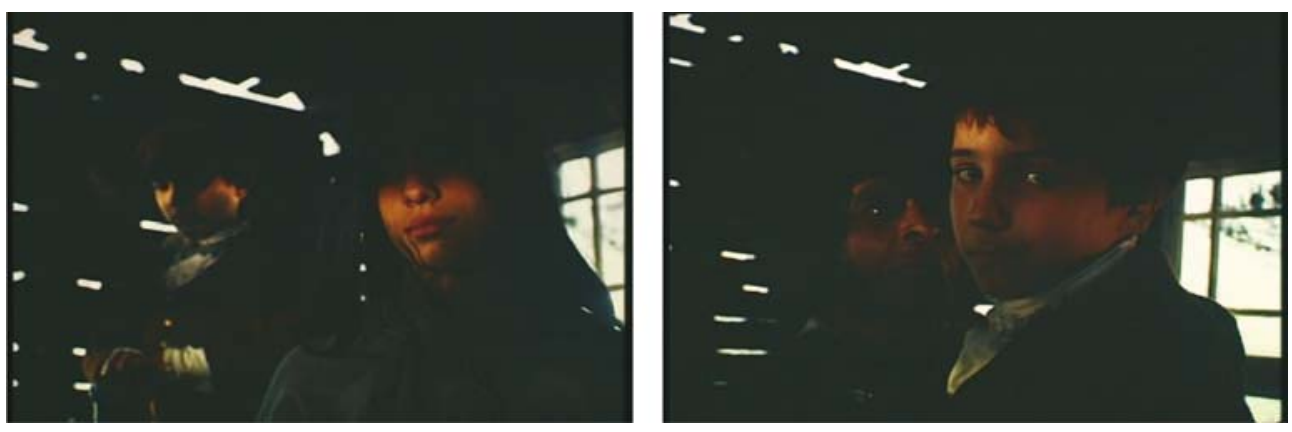

Figures 13-14. Tableau vivant. Caspar David Friedrich: Two Men by the Sea at Moonrise (1817). Éva and David Copperfield at the seaside in András Jeles's Parallel Lives.
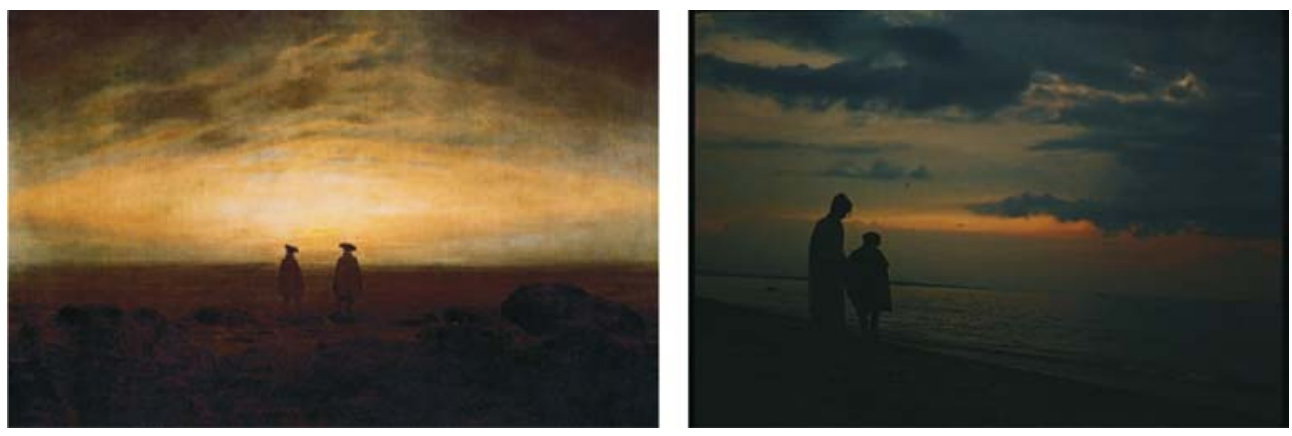

Figures 15-16. Archival footage under the magnifying lens in the closure of Parallel Lives.
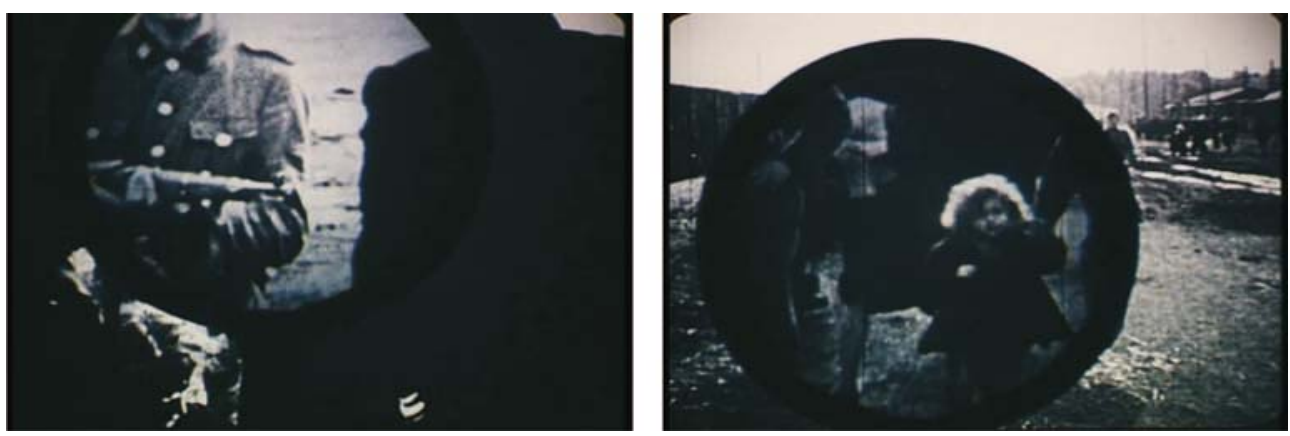
Figures 17-18. The image of the child on archival footage. András Jeles: Parallel Lives / Alain Resnais: Night and Fog (1956); Ingmar Bergman: Persona (1966).
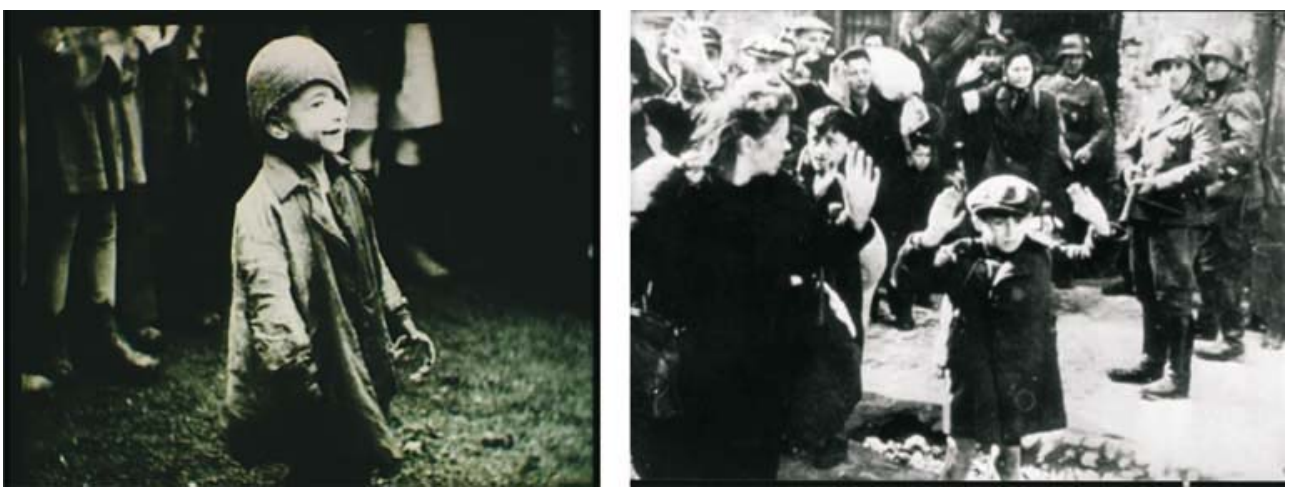